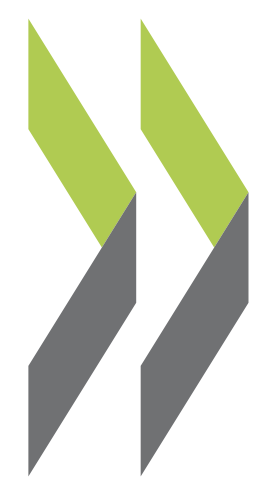

OECD Economics Department Working Papers No. 820

After the Crisis: Mitigating Risks of Macroeconomic

\title{
kukasz Rawdanowicz
} Instability in Turkey

https://dx.doi.org/10.1787/5km36j745fbt-en 
Organisation de Coopération et de Développement Économiques

Organisation for Economic Co-operation and Development

06-Dec-2010

ECONOMICS DEPARTMENT

English - Or. English

AFTER THE CRISIS: MITIGATING RISKS OF MACROECONOMIC INSTABILITY IN TURKEY

ECONOMICS DEPARTMENT WORKING PAPER No. 820

By Lukasz Rawdanowicz

All Economics Department Working papers are available through the OECD internet website at www.oecd.org/workingpapers

JT03293983

Document complet disponible sur OLIS dans son format d'origine

Complete document available on OLIS in its original format 


\section{ABSTRACT/ RÉSUMÉ}

\section{After the crisis: mitigating risks of macroeconomic instability in Turkey}

Turkey is recovering from a severe recession. Once growth gains full speed, the authorities will likely face the challenge of widening external imbalances and of ensuring a smooth functioning of the financial markets. The former will require improving competitiveness, raising domestic saving, attracting more FDI inflows and reducing energy import dependency. Improvements in many of these areas will depend on structural reforms in the labour and product markets. Financial market stability calls for adopting international standards of prudential regulations and reacting pre-emptively to new developments in the financial markets. Mitigating risks of macroeconomic instability will be crucial for embarking on a stable and strong growth path to generate sustainable convergence with the OECD average income level. This paper relates to the 2010 OECD Economic Review of Turkey (www.oecd.org/eco/surveys/turkey).

JEL Classification: C5; E21; F32, F41; G18; H3; Q43

Key words: Turkey; current account deficit; trade model; competitiveness; saving; FDI; energy import dependence; financial supervision

$* * * * * * * * * * * * * * * * * * * * * * * *$

\section{Après la crise: réduire les risques d'instabilité macroéconomique en Turquie}

La Turquie se remet de sa récession la plus grave depuis plusieurs décennies. Quand la croissance prendra son plein essor, les autorités devront faire face au défi de l'élargissement des déséquilibres extérieurs et d'assurer un bon fonctionnement des marchés financiers. Concernant le premier défi, il faudra améliorer la compétitivité, augmenter l'épargne nationale, attirer davantage d'investissement direct étranger et réduire la dépendance vis-à-vis des importations d'énergie. Des améliorations dans plusieurs de ces domaines dépendront de réformes structurelles dans les marchés du travail et des produits. La stabilité des marchés financiers requiert l'adoption des normes internationales de réglementation prudentielle et des initiatives à titre préventif pour faire face aux nouveaux développements dans les marchés financiers. Atténuer les risques d'instabilité macroéconomique sera crucial pour embarquer sur un sentier stable et solide de croissance pour rattraper le niveau de revenu moyen des pays de l'OCDE. Ce document se rapporte à l'Étude économique de Turquie de l'OCDE, 2010, (www.oecd.org/eco/etudes/turquie).

Classification JEL : C5; E21; F32, F41; G18; H3; Q43

Mots clés : Turquie ; déficit du compte courant ; modèle de commerce ; compétitivité ; épargne ; investissement direct étranger ; dépendance énergétique ; surveillance financière

\section{Copyright OECD 2010}

Application for permission to reproduce or translate all, or part of, this material should be made to: Head of Publications Service, OECD, 2 rue André-Pascal, 75775 Paris cedex 16, France. 


\section{TABLE OF CONTENTS}

\section{AFTER THE CRISIS: MITIGATING RISKS OF MACROECONOMIC INSTABILITY IN TURKEY .....5}

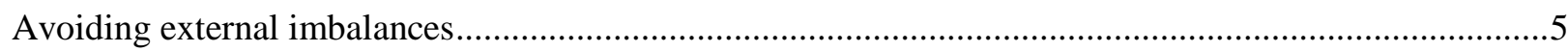

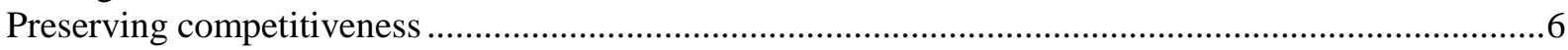

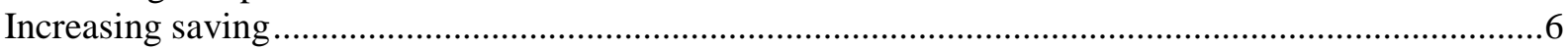

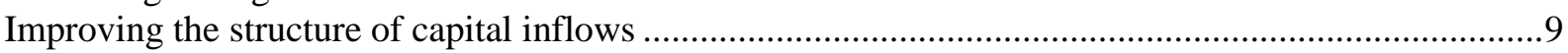

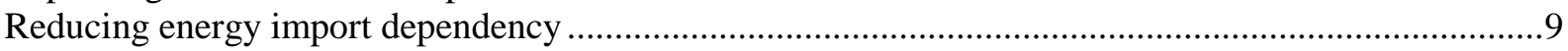

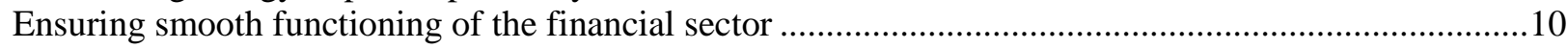

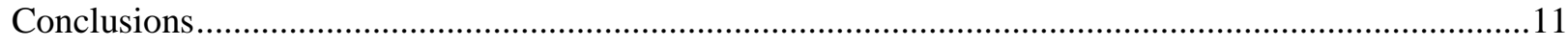

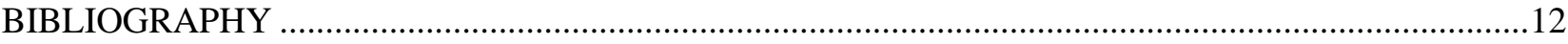

ANNEX A1. CURRENT ACCOUNT DEFICIT AND EXTERNAL DEBT SIMULATIONS WITH

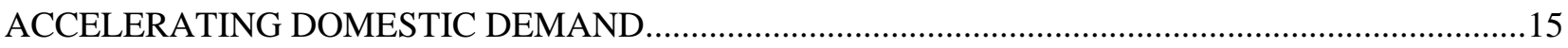

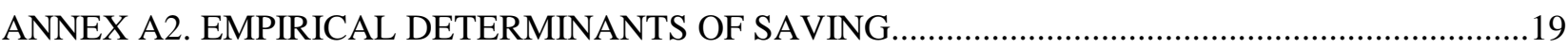

\section{Tables}

Table A1.1. Assumptions underlying medium-term simulations of the current account balance and

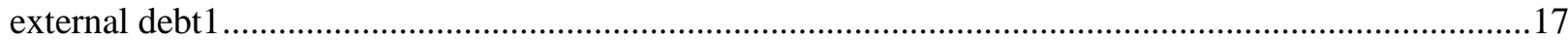

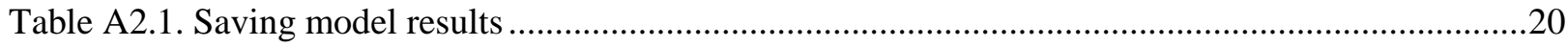

Table A2.2. Robustness checks of the saving models estimated for the first group of countries ...............22

Table A2.3. Robustness checks of the saving models estimated for the second group of countries .........23

Table A2.4. Robustness checks of the saving models estimated for the third group of countries .............24

\section{Figures}

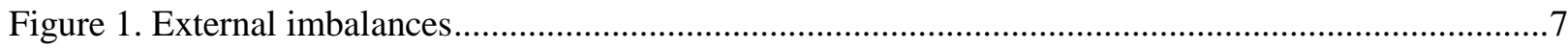

Figure A1.1. Differences in current account and foreign debt simulations with accelerating domestic demand.

\section{Boxes}

Box 1. Policies to increase saving. 
ECO/WKP(2010)76 
ECO/WKP(2010)76

\title{
AFTER THE CRISIS: MITIGATING RISKS OF MACROECONOMIC INSTABILITY IN TURKEY
}

\author{
By Łukasz Rawdanowicz ${ }^{1}$
}

Following two decades of a volatile macroeconomic environment, Turkey has experienced the benefits of an improved macroeconomic policy regime in the 2000s. This was possible thanks to important improvements in macroeconomic policy. Budget deficits were significantly reduced and public debt, as a percentage of GDP, declined. The central bank was made independent and an explicit inflation targeting framework was introduced. These reforms were instrumental for successfully starting disinflation. Moreover, the banking sector was restructured and banking supervision enhanced. This, combined with greater political stability, helped reduce risk premia and capital costs and boosted business activities, especially among globally-oriented large and medium-sized companies. Turkey also strengthened its relations with the European Union and started a harmonisation process to fulfil the acquis, which had a positive impact on investor confidence.

The 2008-09 global crisis, being a serious external shock for Turkey, affected tangibly the Turkish economy (Rawdanowicz, 2010). This event has again highlighted costs of macroeconomic instability and brought to attention, in Turkey as in other OECD countries, the importance of sound macroeconomic policies during booms. Turkey has been recovering swiftly from the recession, in part due to good policies and a relatively sound position prior to the crisis, and the full recovery is in prospect. This should not lead however to neglecting future risks to macroeconomic instability. In this context, Turkey should consolidate the achievements from the 2000s and continue improving the policy framework. It should also minimise risks to macroeconomic stability stemming from external imbalances and financial markets once growth gains full speed. This calls for implementing structural reforms and appropriate pre-emptive prudential regulations.

\section{Avoiding external imbalances}

Turkey has a record of high current account imbalances (Figure 1), which preceded Turkish financial crises in 1994 and 2001. Although the current account deficit narrowed significantly in the crisis, it has widened again with the economic recovery. The simulations based on an estimated trade model (Annex A1), which takes into account improvements in non-price competitiveness, suggest that, given the current structure of the Turkish economy, strong demand growth is not compatible with low current account deficits and foreign debt. The implied excessive growth in external imbalances would likely spark capital outflows and in turn a correction in the exchange rate and/or domestic demand, which might ultimately threaten macroeconomic and financial stability. ${ }^{2}$ The recent financial global crisis demonstrated

1. Economist in the OECD Economics Department. This paper builds on Chapter 1 of the 2010 OECD Economic Survey of Turkey. The views expressed in this paper are those of the author and do not necessarily represent those of the OECD or its member countries. The author thanks OECD staff member Andrew Dean, Robert Ford, Andreas Wörgötter, Rauf Gönenç for valuable comments. Excellent statistical assistance from Béatrice Guerard and secretarial assistance from Josiane Gutierrez and Pascal Halim are gratefully acknowledged.

2. The macroeconomic correction due to external imbalances is however neither automatic nor imminent. Usually it is difficult to predict a critical level of the current account deficit/foreign debt, the timing of the correction as well as its mechanism (exchange rate and/or domestic demand). Nevertheless, current account deficits are among the key predictors of financial crises (e.g. in Kaminsky et al., 1997). 


\section{ECO/WKP(2010)76}

that capital reversals do not have to be triggered by domestic developments and that emerging markets with high current account deficits and heavy dependence on foreign financing, experienced particularly sharp output contractions (e.g. Estonia, Bulgaria, Latvia, Lithuania and Romania). This does not however imply that low and moderate current account deficits are necessarily bad for Turkey, as they may facilitate higher investment and thus stronger future growth.

The authorities could consider policies to rein in an excessive widening of external imbalances. Four areas deserve particular attention: international competitiveness, saving, the structure of capital inflows and energy import dependency. Effective policies in these areas would not only have a positive effect on current account balances but also on long-term growth (Gönenç and Rawdanowicz, 2010). Once such policies are in place, Turkey will be more likely to grow strongly without excessively high current account deficits.

\section{Preserving competitiveness}

Price and non-price competitiveness are important determinants of current account balances (Annex A1). Non-price competitiveness - understood broadly as factors affecting firms' ability to innovate and improve products' quality - has improved in the 2000s, but there is still much scope for progress (Gönenç and Rawdanowicz, 2010). Regarding price competitiveness, the picture is mixed. Previous OECD surveys documented that the labour intensive sectors of the Turkish economy faced serious competitiveness and employment losses, while medium-technology based activities coped well and continued to grow strongly (OECD, 2006, 2008a). Although, currently there is no strong evidence of exchange rate overvaluation, high labour costs, as demonstrated in Gönenç and Rawdanowicz (2010), and the loss of export market share prior to the crisis suggest price competition pressures. Looking into the future, the authorities should focus on further enhancing non-price competitiveness and preserving price competitiveness. This primarily requires improving labour and product market regulations to back productivity gains and making wage setting (including minimum wages) more responsive to economic circumstances. Specific policies are discussed in Gönenç and Rawdanowicz (2010). Moreover, macroeconomic policy should be geared to maintaining the real exchange rate close to its fundamentals. This will be especially important as strong nominal exchange rate appreciation after the crisis is likely to occur. Once the domestic and international environment improves, Turkey will likely experience increased capital inflows and exchange rate appreciation, as already was the case in the 2000s (OECD, 2008a). Consequently, corporate saving, employment and growth in the tradables sector may be seriously affected (see below and Annex A2). ${ }^{3}$ Incipient nominal exchange rate appreciation pressures have already been observed in the first half of 2010. If the authorities would decide to engage in direct measures to prevent excessive nominal exchange rate appreciation (like foreign exchange intervention or capital controls), it should be stressed that such measures cannot be a substitute to structural reforms to improve competiveness and to lower labour costs.

\section{Increasing saving}

Increasing domestic saving would help sustain robust economic expansion without fuelling external imbalances and risking turbulent corrections. Turkey will likely need much higher investment than in recent years to sustain GDP expansion in the future. The World Bank (2008) estimates that Turkey would require investment at above $30 \%$ of GDP to sustain growth of 6-7\%. The ratio was on average around $20 \%$ of GDP in the 2003-08 period (Figure 1). In the absence of sufficient domestic saving, high investment

3. Overvalued exchange rates are believed to lower economic growth (Eichengreen, 2008; Rodrik, 2008). In the particular case of Turkey, the real exchange appreciation was found to diminish significantly profit margins in the manufacturing industry, especially in the sectors using low-skilled labour (Yilmaz and Gönenç, 2008). 
will have to be financed from abroad. However, international experience shows that it is difficult to achieve sustained and strong investment without sufficient domestic saving (Commission on Growth and Development, 2008).

Figure 1. External imbalances

$\%$ of GDP
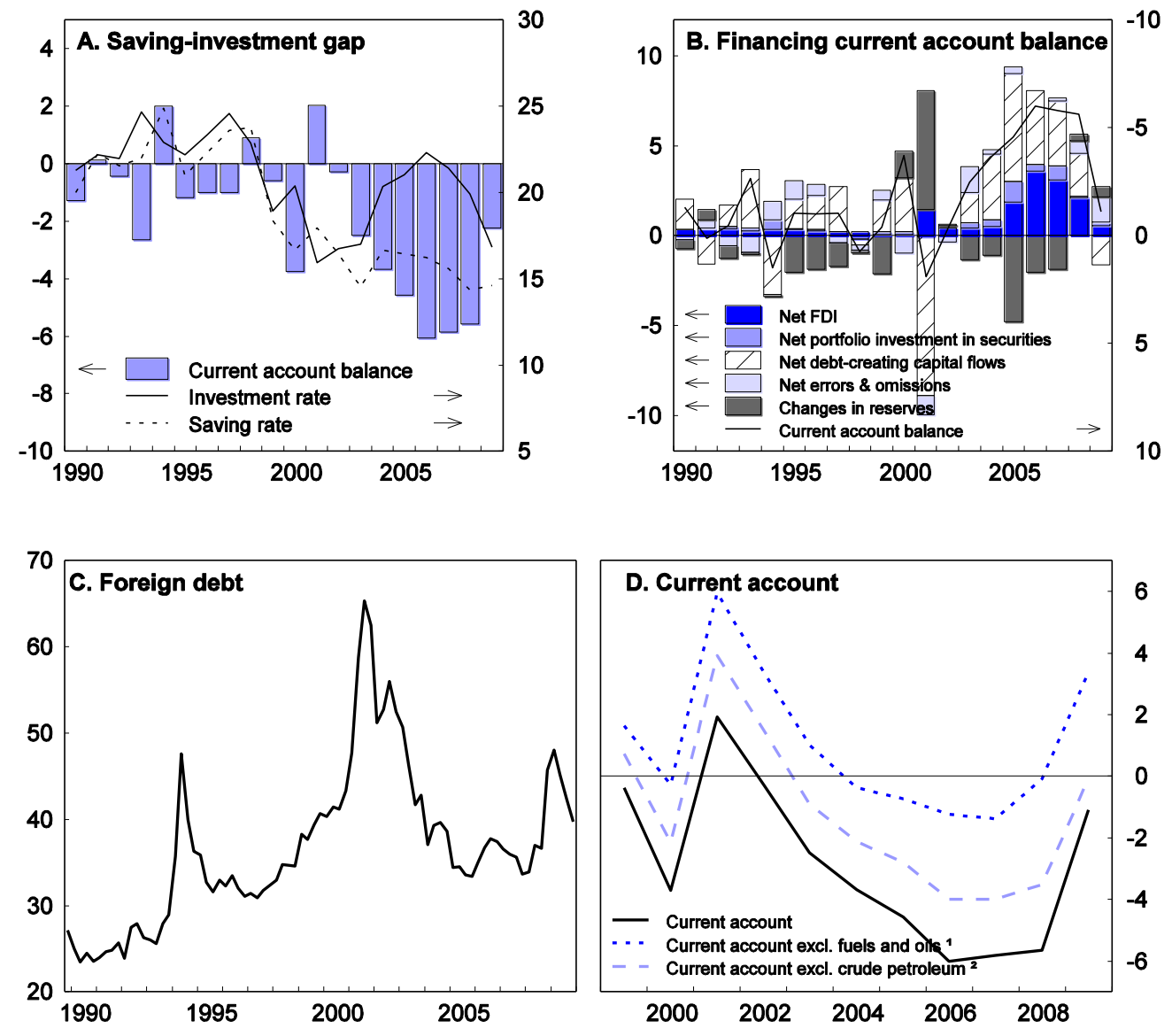

1. Excluding net exports of processed and unprocessed fuels and oils and gasoline (according to Board Economic Categories).

2. Excluding only imports of crude petroleum.

Source: OECD, OECD Economic Outlook Database; IMF, International Financial Statistics Database and CBRT.

The investment driven widening of the current account balance was already observed in the 2000s (Figure 1). The impact on external balances was then exacerbated by a fall in saving. The overall saving rate declined strongly between the late 1990s and the early 2000s and, after a temporary reversal, it continued falling in the following years, but at a lower rate. In the first period, the drop in saving coincided with high budget deficits, whereas in the second phase the reverse was true, implying a fall in private saving. ${ }^{4}$

4. Assessing precisely the contributions of private (household and corporate) and of public saving is complicated by the lack of reliable data. Total saving is calculated as a sum of the current account balance and investment. 


\section{ECO/WKP(2010)76}

Saving can be affected by policies to boosting saving, and by changes in macroeconomic fundamentals. Direct policies to increase domestic saving are numerous but their effects are often contested and uncertain (Box 1). In the Turkish case, it seems that fiscal discipline may be the best and direct way to raise total domestic saving, adding another argument for fiscal discipline. Implementing tax incentives and altering the tax structure to boost saving are not recommended for Turkey before dealing with pervasive informality and tax evasion.

\section{Box 1. Policies to increase saving}

Despite voluminous research on policies to increase domestic saving, no consensus has been reached on the best measures and the effectiveness of particular solutions. This box reviews selected policies.

Public saving. Increasing public saving is often claimed to be the most direct and effective, though not always politically feasible, way of boosting private saving (Loayza et al., 2000a). This policy is effective if public saving does not fully crowd out private saving, contrary to the implications of the Ricardian equivalence theory. Available empirical evidence indicates that indeed Ricardian equivalence does not hold in Turkey (Akbostanci and Tunç, 2002; Metin-Ozcan et al., 2003) and in other countries (Lopez et al., 2000). Improved public finances may also have positive indirect long-run effects on private saving: with lower budget deficits more private saving could be channelled to domestic investment, boosting economic growth and in turn private saving (Dayal-Gulati and Thimann, 1997; Loayza et al., 2000a).

Tax incentives. Such measures are controversial (Bernheim, 2002) and are frequently judged as ineffective in raising saving rates (Loayza et al., 2000a). The assessment of tax measures is complicated by difficulties in estimating the elasticity of saving with respect to the rate of net return. There is a theoretical and empirical debate regarding the sign and magnitude of the elasticity, making predictions difficult, especially on a macro scale. Consequently the evidence of positive effects of tax incentives on saving is scarce (Loayza et al., 2000a). Tax incentives may also involve high administration costs and create difficult to predict distortions.

Tax structure. Another way in which tax policy can affect saving relates to the tax structure and its anti-saving distortions. Shifting taxation from income to consumption is believed to boost private saving (Tanzi and Zee, 1998). Taxation in Turkey is already skewed towards consumption taxes. Indirect taxes accounted for around $45 \%$ of all tax revenue in 2007. This skew reflects mostly a pervasive evasion of personal income tax, rather than very high indirect tax rates (some exception refer to special consumption and excise taxes) or/and very low personal income tax rates.

Financial sector. Financial sector development and liberalisation have ambiguous effects on saving (Bandiera et al., 2000; Loayza et al., 2000a), though they are likely to be positive in the long run. In the short run, a greater availability of credit and eased liquidity constraints are usually found to reduce private saving (Loayza et al., 2000b). However, some positive short-run effect can also be expected: for instance, wider access to mortgages may stimulate private saving for the down payment. In the long run, a robust and efficient financial sector is likely to bolster investment and economic growth and to provide access to more attractive and diversified saving instruments, stimulating private saving. In this respect, institutional support to stock market development could be considered. The recent global events demonstrated, however, that financial market innovations, if not properly supervised, may lead to bubbles and capital misallocation. Thus, effective financial market supervision must be ensured. This could be accompanied by policies to increase the level of financial education. Explaining the purposes of saving and informing about saving possibilities are believed to affect private saving positively (Bernanke, 2006; OECD, 2008b).

A more effective way, however, would seem to be to focus on policies affecting key macroeconomic determinants of saving, in particular on employment, real exchange rate and economic growth. Implementing structural reforms to improve productivity and employment and ensuring that macroeconomic policies do not lead to excessive exchange rate overvaluation is expected to boost saving. In recent years, the falling and very low employment rate increased the number of households dependent on the income of only one earner, reducing income per head and in turn making saving difficult. In parallel, real exchange rate appreciation seemed to have reduced the average margins of manufacturing firms (Yilmaz and Gönenç, 2008) and in turn lowered corporate saving. ${ }^{5}$ These two factors are indeed found to affect saving negatively in the empirical cross-country analysis presented in Annex A1. Private saving should also rise alongside higher GDP growth (Loayza et al., 2000a, b).

5. A similar argument is made by Rodrik (2009b). 


\section{Improving the structure of capital inflows}

Increasing the share of foreign direct investment (FDI) and equity portfolio investment (the so-called non-debt creating capital) in overall capital flows would mitigate the risk of an abrupt current account correction and would likely improve the trade balance over time. FDI inflows are more stable than portfolio investment and less sensitive to short-term macroeconomic developments. The non-debt creating capital inflows affect foreign debt dynamics positively, limiting external vulnerabilities (Annex A1). FDI inflows are associated with a transfer of technologies and new investment; when invested in the tradable sector, they are likely to improve productive capacities and thus the trade balance.

In the mid-2000s, domestic market-oriented FDI inflows in service sectors increased considerably (Figure 1). This likely reflected a more stable and predictable macroeconomic and political environment as well as the easing product market regulations (Gönenç and Rawdanowicz, 2010). Regarding the latter, Turkey has considerably reduced barriers to foreign investment in 2003 by enacting a law which eliminated the special regime of foreign owned corporations and granted full national treatment to all foreign enterprises operating in Turkey. Nonetheless, a number of barriers still remain and attracting higher FDI inflows, especially in exporter industries, will require further improving general conditions for doing business and further lowering certain specific barriers to foreign investment. Concerning obstacles to doing business, barriers to entry should be reduced by simplifying the licence and permits system, streamlining the legal and regulatory framework and limiting excessive discretionary powers of regulatory authorities (Gönenç and Rawdanowicz, 2010). Concerning specific barriers to FDI, sectoral investment restrictions such as on radio and TV broadcasting, energy and transport, and relatively cumbersome conditions for foreigners' work permits are areas where additional liberalisation would be welcome.

Attracting FDI could also benefit from higher domestic saving, as such saving is found to be important for FDI co-financing, especially in countries that are far from the technological frontier (Aghion et al., 2006).

\section{Reducing energy import dependency}

Lower energy import dependence and higher energy efficiency would help redress current account imbalances. Energy self-sufficiency in Turkey was around 30\% in 2008 (IEA, 2009), implying a heavy reliance on energy imports. Consequently, trade deficits in energy were high (Figure 1). This may reflect Turkey's current comparative advantage. This could however change thanks to deliberate policies. The energy import dependence may diminish if government's targets to increase the production of energy from nuclear power and renewable sources of energy are achieved. The government envisages to supply 5\% of energy by 2020 from nuclear power plants, and obtaining $30 \%$ of electricity generation from renewable sources by 2023 (SPO, 2009b). Given Turkey's specific geophysical conditions, particularly high safety standards for nuclear energy should be ensured. At the same time, the efficiency of the production and consumption of energy should be improved. This requires minimising waste, energy intensity and technical losses during the generation, transmission and distribution of energy. In addition, the effective functioning of the internal energy market should be ensured. The recent decisions to privatise distribution assets and regional distribution facilities and to implement cost-based pricing mechanisms should contribute to achieving this goal.

A successful energy strategy would also support stronger economic growth. Power outages are common in Turkey, adversely affecting economic activity. Turkish businessmen report on average six power outages per month, which are particularly severe for the manufacturing sector (Enterprise Survey, 2009). Electricity failures highlight more generally the challenges for the security of energy provision, which have raised concerns in the past (IMF, 2008). In this respect, appropriate investment in energy infrastructure is needed to ensure sufficient energy supply and its uninterrupted distribution. The security 
of gas provision is expected to improve upon accomplishing the Nabucco pipeline project. The pipeline will traverse Turkey, connecting the Caspian region, Middle East and Egypt with western European countries, and is estimated to start operating in 2014.

The energy strategy has to be sustainable in terms of its environmental impact. The assessment of Turkey's environmental conditions is mixed. Regarding greenhouse gas emissions, the $\mathrm{CO}_{2}$ emission per capita is one of the lowest in the OECD but, when measured per GDP at market exchange rates, it is among the highest in the OECD. Since 1990, Turkey has doubled its $\mathrm{CO}_{2}$ emissions. This was among the largest increases observed in the OECD countries (IEA, 2009). Moreover, the $\mathrm{CO}_{2}$ intensity of electricity and heat production in 2007 was among the highest, even if it declined from 1990. In addition, ambient air pollution by sulphur dioxide $\left(\mathrm{SO}_{2}\right)$ and nitrogen monoxide $\left(\mathrm{NO}_{\mathrm{x}}\right)$ exceeds national air quality standards (OECD, 2008c). Turkey's share of renewables in total primary energy supply was below $10 \%$ in 2008 , which was higher than the OECD average (IEA, 2009). Given the projected increase in energy consumption, reaching the targets for renewable energy production (see above) would require significant investment. By and large, although the environmental impact of energy production and consumption is not alarming, there is scope for improvement, especially as the continuing rapid economic development is likely to intensify some of the environmental challenges.

\section{Ensuring smooth functioning of the financial sector}

A smooth functioning of the financial markets and prudent financial supervision are key to macroeconomic stability. Turkey has painfully learned this lesson in 2001 (BRSA, 2009; Bredenkamp et al., 2009), and the OECD countries were reminded about it during the recent crisis. The efficient functioning of the financial system will be also instrumental for lowering the cost of capital and in turn for boosting economic growth (Gönenç et al., 2010).

The current situation in the Turkish financial sector is significantly better than in many OECD countries, but there are still some challenges and scope for improvement.

In the very short term, it is highly welcome that certain measures taken in early 2009 to relax some of the prudential rules applicable to banks in order to ease credit conditions for businesses are kept temporary. A decree published on 16 June 2009 gave additional margins to banks to restructure loans for squeezed corporate customers without necessarily re-classifying their loans and undermining their creditworthy borrower status (CBRT, 2010). Certain capital provisioning rules for new credits extended after June 2009 were also temporarily relaxed. These measures will be phased out as of 1 March 2011.

As international experience shows a shift to low inflation and interest rates in emerging markets leads often to rapid credit growth and asset price bubbles. This calls for prudent monetary policy and financial supervision. In this context, an excessive growth of housing loans should also be avoided and minimum downward payment rules should be kept prudent. Moreover, fast innovation in the financial markets requires constant vigilance and adapting to an ever changing situation.

Low inflation and interest rates and higher competition will likely affect banks' profitability in different directions. Such an environment is likely to lower risk premia, especially for longer-term borrowing, and in turn financing costs for banks (Gönenç et al., 2010). But it may also weigh on banks' margins and reduce deposit volumes, requiring new financing sources. Banks' profitability may also be negatively affected by a shift in the asset structure away from government securities to credits and by increased competition.

Turkish authorities have already demonstrated their readiness to adjust prudential regulations preemptively. Despite the low level of foreign currency exposure of households (around $4 \%$ of total consumer 
loans in 2009), in mid-2009 households were forbidden to take foreign exchange and foreign exchange index loans from foreign and domestic banks. ${ }^{6}$ This regulation limits currency risks for households and slows credit growth given a still large interest rate differential. It is a welcome decision given the recent experience with pro-cyclical credit growth in foreign currency in several European emerging countries. Safeguards against foreign exchange rate exposure have therefore been developed.

Adopting Basel II and its new amendments should remain a prime objective of regulators. Basel II is likely to result in lower risk-adjusted capital ratios, particularly due to the required re-pricing of Turkish government securities which constitute a significant share of banks' assets. According to Basel I rules, government securities of the OECD countries are priced as riskless assets, whereas in Basel II they are valued according to their credit rating. The timing of Basel II adoption has not been decided yet, but the progress with implementing required rules continues. Turkey has also a strong interest in complying with amendments to Basel II aiming at countercyclical prudential supervision because it will face more such risks as its integration with the global capital market proceeds. The task should be made easier thanks to the admission of the Turkish Banking Regulation and Supervision Agency (BRSA) to the Basel Committee on Banking Supervision in May 2009 and Turkey's participation in the Financial Stability Board. ${ }^{7}$

\section{Conclusions}

Recurrent macroeconomic instability may have high costs in terms of excessive output volatility and lower long-term growth. Thus, mitigating the risks of such events should remain high on policy agenda. Such risks could be reduced by fully consolidating the macroeconomic framework and external and financial stability. Progress in these areas will not be possible without structural reforms to support Turkey's competitiveness, increase saving, improve the structure of capital inflows towards FDI and lower energy import dependency and without prudent financial regulations. Although domestic and foreign shocks cannot be entirely eliminated, ${ }^{8}$ enhancements in structural policies and the macroeconomic framework is likely to improve resilience to shocks, including by permitting active counter-cyclical polices, as was already the case in 2008-09. Protracted and negative effects of shocks on growth and employment can therefore be limited, boosting long-term growth.

6. In contrast, the access to foreign currency credit for companies, which was very strict, was relaxed. This was motivated notably by concerns about foreign debt statistics. Many companies were taking loans from foreign branches of domestic banks, which inflated foreign debt.

7. The Financial Stability Board, comprising G-20 countries, was established to coordinate at the international level the work of national financial authorities and international standard setting bodies and to develop and promote the implementation of effective regulatory, supervisory and other financial sector policies. In April 2009, it replaced the Financial Stability Forum that involved G-7 countries.

8. Higher output volatility may reflect the production specialisation towards less complex goods which exports are found to be more volatile (Pravin and Levchenko, 2009). Thus, shifting to modern tradables may not only be a way to increase growth, as argued by Rodrik (2009a), but also a mean to reduce output volatility. 


\section{BIBLIOGRAPHY}

Aghion, P., D. Comin and P. Howitt (2006), "When Does Domestic Saving Matter for Economic Growth?”, NBER Working Papers, No. 12275, National Bureau of Economic Research, Cambridge, MA.

Akbostanci, E. and G.I. Tunç (2002), "Turkish Twin Effects: An Error Correction Model of Trade Balance", Economic Research Center Working Papers in Economics, No. 01/06, Middle East Technical University, Ankara.

Armington, P.S. (1969), "A Theory of Demand for Products Distinguished by Place of Production”, IMF Staff Papers, No. 16, IMF, Washington, DC.

Bandiera, O., G. Caprio, P. Honohan and F. Schiantarelli (2000), "Does Financial Reform Raise or Reduce Private Savings?", Review of Economics and Statistics, Vol. 82(2).

Bernanke, B.S. (2006), "The Coming Demographic Transition: Will We Treat Future Generations Fairley?", Speech before the Washington Economic Club, 4 October, Washington, DC.

Bernheim, B.D. (2002), “Taxation and Saving”, in: A.J. Auerbach and M. Feldstein (ed.), Handbook of Public Economics, Vol. 3, Ch. 18, Elsevier, Amsterdam.

Bredenkamp, H., M. Josefsson and C.J. Lindgren (2009), “Turkey’s Renaissance: From Banking Crisis to Economic Revival", in Brau E. and I. McDonald, Successes of the International Monetary Fund: Untold Stories of Cooperation at Work, Palgrave Macmillan.

BRSA (2009), "From Crisis to Financial Stability (Turkey Experience)”, BRSA Working Paper, Banking Regulatory and Supervision Agency, Ankara.

CBRT (2010), Financial Stability Report, Vol. 10, May, Central Bank of the Republic of Turkey, Ankara.

Commission on Growth and Development (2008), The Growth Report. Strategies for Sustained Growth and Inclusive Development, International Bank for Reconstruction and Development and World Bank, Washington, DC.

Dayal-Ghulati, A. and C. Thimann (1997), "Saving in Southeast Asia and Latin America Compared: Searching for Policy Lessons", IMF Working Papers, No. 97/110, IMF, Washington, DC.

Edwards, S. (1995), "Why Are Saving Rates So Different across Countries? An International Comparative Analysis", NBER Working Papers, No. 5097, National Bureau of Economic Research, Cambridge, MA.

Eichengreen, B. (2008), "The Real Exchange Rate and Economic Growth", Commission on Growth and Development Working Papers, No. 4, Washington, DC.

Enterprise Surveys (2009), "Running a Business in Turkey", Enterprise Surveys Country Note Series, No. 1, World Bank Group, Washington, DC.

Ericsson, N.R. and J.G. MacKinnon (2002), "Distributions of Error Correction Tests for Cointegration", Econometrics Journal, Vol. 5, p. 285-318.

Gagnon, J.E. (2007), "Productive Capacity, Product Varieties, and the Elasticities Approach to the Trade Balance", Review of International Economics, Vol. 15, p. 639-659. 
Gönenç, R. and Ł. Rawdanowicz (2010), "Regulatory Reforms to Unlock Long-Term Growth in Turkey", OECD Economics Department Working Papers, No. 821, OECD, Paris.

Gönenç, R., S. Şahinöz and S.Ö. Tuncel (2010), “Fostering Turkey's Sound Integration in the Global Capital Market”, OECD Economics Department Working Papers, No. 812, OECD, Paris.

Government (2009), Action Plan of Strategy for Fight against the Informal Economy (2008-2009), Presidency of Revenue Administration, Department of Strategy Development, No. 88, Ankara.

Hooper, P., K. Johnson and J. Marquez (1998), “Trade Elasticities for G-7 Countries”, International Finance Discussion Papers, No. 609, Board of Governors of the Federal Reserve System, Washington, DC.

IEA (2009), IEA Scoreboard 2009. 35 Key Energy Trends over 35 Years, International Energy Agency, Paris.

IMF (2008), "Turkey: Seventh Review and Inflation Consultation under the Stand-By Arrangement and Request for Wavier of Nonobservance of Performance Criteria", IMF Country Report, No. 08/272, August, Washington, DC.

Kaminsky, G., S. Linzondo and C. Reihart (1997), "Leading Indicators of Currency Crises", IMF Staff Papers, Vol. 45(1), Washington, DC.

Loayza, N., K. Schmidt-Hebbel and L. Servén (2000a), "Saving in Developing Countries: An Overview", World Bank Economic Review, Vol. 14(3), Washington, DC.

Loayza, N., K. Schmidt-Hebbel and L. Servén (2000b), "What Drives Private Saving across the World?", Review of Economics and Statistics, Vol. 82(2), p. 165-181.

Lopez, H., K. Schmidt-Hebbel and L. Servén (2000), "How Effective Is Fiscal Policy in Raising National Saving?", Review of Economics and Statistics, Vol. 82(2), p. 226-238.

Metin-Ozcan, K., A. Gunay and S. Ertac (2003), "Determinants of Private Savings Behaviour in Turkey", Applied Economics, Vol. 35(12).

OECD (2006), OECD Economic Surveys: Turkey, Vol. 2006/15, OECD, Paris.

OECD (2008a), OECD Economic Surveys: Turkey, Vol. 2008/14, OECD, Paris.

OECD (2008b), Improving Financial Education and Awareness on Insurance and Private Pensions, Paris.

OECD (2008c), OECD Environmental Performance Reviews: Turkey, OECD, Paris.

OECD (2010), OECD Economic Surveys: Turkey, Vol. 2010/13, OECD, Paris.

Pain, N., A. Mourougane, F. Sédillot and L. Le Fouler (2005), "The New OECD International Trade Model”, OECD Economics Department Working Papers, No. ECO/WKP(2005)27, OECD, Paris.

Pravin, K. and A.Al. Levchenko (2009), "Comparative Advantage, Complexity and Volatility", NBER Working Papers, No. 14965, National Bureau of Economic Research, Cambridge, MA.

Rodrik, D. (2008), “The Real Exchange Rate and Economic Growth", Brookings Papers on Economic Activity, Conference Draft, September.

Rodrik, D. (2009a), "Growth after the Crisis”, CEPR Discussion Paper, No. 7480, Centre for Economic Policy Research, London.

Rodrik, D. (2009b), "The Turkish Economy after the Crisis", Turkish Economic Association Discussion Papers, No. 2009/9. 
Rubaszek, M. and Ł. Rawdanowicz (2009), "Economic Convergence and the Fundamental Equilibrium Exchange Rate in Central and Eastern Europe", International Review of Financial Analysis, Vol. 18(5), p. 277-284.

Rawdanowicz, Ł. (2010), "The 2008-09 Crisis in Turkey: Performance, Policy Responses and Challenges for Sustaining the Recovery", OECD Economics Department Working Papers, No. 819, OECD, Paris.

Sato, K. (1977), "The Demand Function for Industrial Exports: A Cross-Country Analysis", Review of Economics and Statistics, Vol. 65, p. 456-64.

Tanzi, V. and H. Zee (1998), "Taxation and the Household Saving Rate: Evidence from OECD Countries", IMF Working Papers, No. 98/36, Washington, DC.

World Bank (2008), "Turkey Country Economic Memorandum. Sustaining High Growth: Selected Issues", World Bank Report, No. 39194-TR, Washington, DC.

Yilmaz, G. and R. Gönenç (2008), "How Did the Turkish Industry Respond to Increased Competitive Pressures, 1998-2007?”, Central Bank of the Republic of Turkey Working Papers, No. 08/04, CBRT, Ankara. 
ECO/WKP(2010)76

\section{ANNEX A1. CURRENT ACCOUNT DEFICIT AND EXTERNAL DEBT SIMULATIONS WITH ACCELERATING DOMESTIC DEMAND}

Current account balances and foreign debt are important indicators of macroeconomic stability in emerging markets. High and protracted current account deficits, especially when they raise foreign debt, may lead to a turbulent correction. In order to gain insights about potential external imbalances in the medium term in Turkey, this annex presents two hypothetical current account and foreign debt simulations based on partial equilibrium analysis, using an estimated trade model. The simulations do not assume any feedback from the current account balance and external debt to other macroeconomic variables, such as exchange rate. Thus, they are not meant to be projections. They simply aim to demonstrate that under the current structure of the economy, Turkey is likely to experience growing external imbalances following sustained domestic demand accelerations.

The Turkish trade model consists of four equations for the prices and volume of exports and imports. Export and import prices are assumed to be determined by domestic and foreign prices in line with the standard practice (Pain et al., 2005). In contrast, volume equations depart from the standard approach, which focuses primarily on demand and relative prices (Pain et al., 2005). ${ }^{9}$ Following the ideas of Sato (1977) and Gagnon (2007), trade volume equations are augmented with a proxy of productive capacities. ${ }^{10}$ This variable aims at capturing non-price competitiveness or other factors explaining international trade (like love for variety, product differentiation, economies of scale, or Rodrik's (2009a) idea about "modern" tradables). The intuition is that fast-growing countries are likely to raise the quality of their products and to encourage innovation, improving ceteris paribus their trade balances. Consequently, the catching-up process involving quality and variety improvements may to some extent mitigate the negative impact of concomitant real exchange rate appreciation.

The trade equations are estimated as error-correction models (ECM). The following long-run relations, derived from the ECM, were obtained (standard errors in brackets): ${ }^{11}$

$$
\begin{aligned}
& m g s v=43.96+2.66 * g d p v-0.39 * r p m-1.30 * r p c \\
& \begin{array}{llll}
(2.96) & (0.11) & (0.12) & (0.25)
\end{array} \\
& x g s v=-4.48+1.00 * x m k t-2.68 * r p x+1.66 * r p c \quad 0.29 \quad 1980-07 \\
& \text { (2.30) (1.16) (0.57) } \\
& (p m g s-p g d p)=-1.18-0.65^{*}(p g d p-p m s h) \rightarrow p m g s=0.35^{*} p g d p+0.65^{*} p m s h \quad 0.82 \quad 1990-07 \\
& \text { (0.11) (0.06) } \\
& \text { adj. } \mathrm{R}^{2} \quad \text { sample } \\
& 0.84 \quad 1993-07
\end{aligned}
$$

9. The so-called Armington's (1969) specification, which implicitly assumes that countries produce one variety of goods and that consumers perceive different varieties originating from a foreign country as perfect substitutes of domestically produced goods.

10. The same idea was used by Rubaszek and Rawdanowicz (2009) to estimate trade equations for the Czech Republic, Hungary, Poland and the Slovak Republic in the context of investigating fundamental equilibrium exchange rates.

11. The short-term dynamics are not shown here. Sample selection was based on the cointegration tests in the single-equation conditional error correction model based on small-sample critical values from Ericsson and MacKinnon (2002). 


$$
\begin{aligned}
(p x g s-p g d p)= & -1.71-0.91 *(p g d p-p x c) \rightarrow p x g s=0.09 * p g d p+0.91 * p x c \quad 0.72 \quad 1990-07 \\
& (0.20)(0.11)
\end{aligned}
$$

where $m g s v$ and $x g s v$ are import and export volumes (goods and services), $g d p v$ is Turkish real GDP, $r p c$ is a proxy of relative productivity capacity defined in terms of average labour productivity (the indicator for Turkey divided by weighted indicators for the main Turkish trading partners), ${ }^{12}$ xmkt is weighted export demand, pmsh is the weighted export price of Turkey's trade partners, $p x c$ is weighted export prices of Turkey's main competitors in foreign markets, pgdp, pmgs and pxgs are Turkey's GDP, import and export deflators respectively, rpm is relative import price (pmgs - pgdp), and rpx is relative export price (pxgs$p x c) .{ }^{13}$ All above-mentioned price indices are denominated in the Turkish lira. Small letters denote variables in logarithms.

The estimated equations have good statistical properties and reasonable economic interpretation in general (in terms of the signs and magnitudes of the long-term elasticities). ${ }^{14}$ In particular, the relative productive capacity proxy is statistically significant and has the expected sign. It implies that if the productivity catching-up continues, Turkey will, ceteris paribus, import less and export more. Following Pain et al. (2005), the demand elasticity in the export equation was restricted to 1, however, in contrast, a similar restriction in import equation was not imposed as it is strongly rejected by the data and it is inconsistent with the fact that since the early 1990s the share of imports in GDP (in real terms) increased from 0.10 to $0.30 .{ }^{15}$ The estimated price equations suggest that Turkey is a price taker, i.e. import and export prices are determined primarily by foreign prices. This is in line with expectations, though the high elasticities on foreign prices may be affected by the large volatility in nominal exchange rates experienced in Turkey over the estimation period.

Combining equations (1)-(4), the current account identity is given by:

$$
\mathrm{CA}_{\mathrm{t}}=\mathrm{PXGS}_{\mathrm{t}} * \mathrm{XGSV}_{\mathrm{t}}-\mathrm{PMGS}_{\mathrm{t}} * \mathrm{MGSV}_{\mathrm{t}}+\mathrm{CA}_{\mathrm{t}}^{\mathrm{TR}}+\mathrm{CA}_{\mathrm{t}}^{\mathrm{INC}}
$$

where $\mathrm{CA}_{\mathrm{t}}^{\mathrm{TR}}$ and $\mathrm{CA}_{\mathrm{t}}^{\mathrm{INC}}$ are transfer and income items of the current account balance.

Given the current account projections, the external debt can be calculated as:

$$
\mathrm{ED}_{\mathrm{t}}=\mathrm{ED}_{\mathrm{t}-1}-\left(\mathrm{CA}_{\mathrm{t}}+\mathrm{NDC}_{\mathrm{t}}\right)
$$

where $\mathrm{ED}_{\mathrm{t}}$ is external debt, $\mathrm{CA}_{\mathrm{t}}$ is the current account balance, and $\mathrm{NDC}_{\mathrm{t}}$ is non-debt creating capital inflows (FDI and equity portfolio capital). ${ }^{16}$ All the above variables are expressed in Turkish lira.

12. Other proxies were also tested (relative potential output per capita and per worker), but the resulting statistical properties of the estimated models were inferior. Only main OECD trading partners are included due to data limitations.

13. For detailed definitions of $x m k t, p m s h$ and $p x c$ refer to Pain et al. (2005).

14. Export volume equation has exceptionally poor properties. Problems with estimating well-behaving trade equations are however common in the literature (Hooper et al., 1998; Pain et al., 2005). The equations without relative productive capacity proxy performed even worse. Pain et al. (2005) attempted to improve the standard trade model specification by adding a deterministic time trend in the long-term equation.

15. The restricted import equation has much worse statistical and economic properties (i.e. less explanatory power, unstable signs and insignificant elasticities).

16. This is a simple version of external debt dynamics which presumes that interest payments on foreign debt are included in the current account balance. For the sake of simplicity, these payments are assumed to be independent of the level of foreign debt. 
ECO/WKP(2010)76

Table A1.1. Assumptions underlying medium-term simulations of the current account balance and external debt1

\begin{tabular}{|c|c|c|c|c|c|}
\hline \multirow{3}{*}{ Domestic variables } & & \multirow[t]{2}{*}{ Simulation 1} & \multirow[t]{2}{*}{ Simulation 2} & \multicolumn{2}{|c|}{ Historic average } \\
\hline & & & & $\begin{array}{l}1998- \\
2007\end{array}$ & $\begin{array}{l}2003- \\
2007\end{array}$ \\
\hline & & & & & \\
\hline Real GDP & GDPV & 4.0 & 5.0 & 4.2 & 6.9 \\
\hline Total employment & ET & 1.2 & 2.2 & 0.7 & 1.1 \\
\hline GDP deflator & PGDP & 5.0 & 5.0 & 33.2 & 11.8 \\
\hline Nominal exchange rate (USD per TRY) ${ }^{2}$ & $\mathrm{EXCH}$ & 0.0 & 0.0 & -16.1 & 3.6 \\
\hline Transfer and income accounts (\% of GDP) & $C A^{T R}+C A^{I N C}$ & -1.0 & -1.0 & -1.1 & -1.1 \\
\hline Non-debt creating capital flows (\% of GDP) & NDC & 1.9 & 1.9 & 1.5 & 2.5 \\
\hline Foreign variables & & & & & \\
\hline Foreign productive capacity & PCF & 1.0 & 1.0 & 1.2 & 1.1 \\
\hline Foreign demand & XMKT & 8.0 & 8.0 & 7.5 & 8.9 \\
\hline Foreign import prices in USD & PMSHF & 3.5 & 3.5 & 3.8 & 9.9 \\
\hline Turkey's competitors' export prices in USD & PXCF & 3.0 & 3.0 & 3.0 & 8.3 \\
\hline Implied variables & & & & & \\
\hline Turkey's productive capacity & $P C=G D P V / E T$ & 2.8 & 2.8 & 3.5 & 5.8 \\
\hline Relative productive capacities & $\mathrm{RPC}=\mathrm{PC} / \mathrm{PCF}$ & 1.8 & 1.8 & 2.3 & 4.6 \\
\hline Foreign import prices in TRY & $\mathrm{PMSH}=\mathrm{PMSHF} / \mathrm{EXCH}$ & 3.5 & 3.5 & 31.4 & 5.8 \\
\hline Turkey's competitors' export prices in TRY & $\mathrm{PXC}=\mathrm{PXCF} / \mathrm{EXCH}$ & 3.0 & 3.0 & 3.0 & 8.3 \\
\hline Relative import prices & $\mathrm{RPM}=\mathrm{PMGS} / \mathrm{PMSH}$ & -1.3 & -1.3 & -0.6 & -3.1 \\
\hline Relative export prices & $\mathrm{RPX}=\mathrm{PXGS} / \mathrm{PXC}$ & -0.2 & -0.2 & -1.4 & -2.9 \\
\hline
\end{tabular}

1. Annual average growth rates unless stated otherwise.

2. An increase means an appreciation of the Turkish lira (TRY).

Source: OECD based on the OECD Economic Outlook Database.

In order to demonstrate the sensitivity of current account balance, and external debt, to acceleration in domestic demand two hypothetical medium-term simulations are presented. They are derived from the estimated trade model and are based on two alternative demand assumptions (Table A1.1). Simulation 1 assumes constant GDP growth of $4 \%$ over a five-year period, whereas Simulation 2 envisages growth of $5 \%$. Higher demand growth in Simulation 2 does not imply higher productivity as the employment growth assumption is also higher in Simulation 2 and the improvement in non-price competitiveness is the same in both simulations. Thus, Simulation 2 implies a demand shock. For the sake of simplicity, all other variables are assumed to be the same in both scenarios and are calibrated to reflect broadly their average past trends.

The hypothetical exercise shows that even small sustained differences in domestic demand growth over the medium term have a tangible impact on the current account deficit and external debt (Figure A1.1). This suggests, given the current structure of the economy and absent real exchange rate adjustments, an incompatibility of strong growth and current account deficit sustainability, despite the ongoing improvements in non-price competitiveness. The implied pace of external imbalances growth would likely trigger corrections in GDP growth and/or the exchange rate. However, reforms to change the structure of the economy, beyond the direct impact of non-price competitiveness, could reduce the required constraint on growth and the real exchange rate to achieve the needed improvement in the external balance. If successfully implemented, Turkey would be able to enjoy strong GDP growth, even stronger than in Simulation 2, without excessive current account deficits. 
ECO/WKP(2010)76

Figure A1.1. Differences in current account and foreign debt simulations with accelerating domestic demand Percentage points
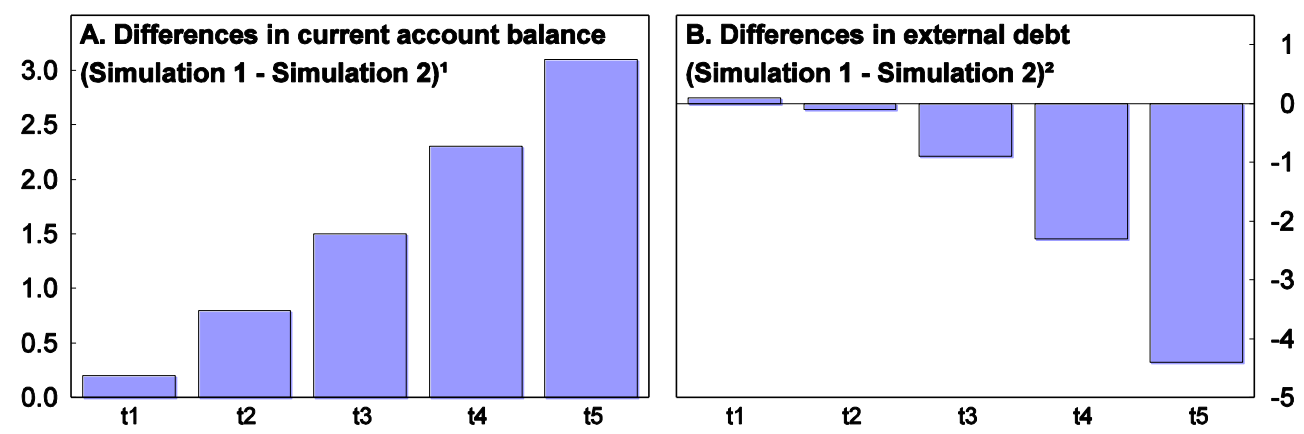

1. Positive figures imply that current account deficit, as a percentage of GDP, in Simulation 1 is lower than in Simulation 2 .

2. Negative figures imply that external debt, as a percentage of GDP, in Simulation 1 is lower than in Simulation 2. Note: Time scale refers to years.

Source: OECD calculations based on the OECD Economic Outlook Database. 
ECO/WKP(2010)76

\section{ANNEX A2. EMPIRICAL DETERMINANTS OF SAVING}

Empirical determinants of saving have been extensively tested in the economic literature (e.g. Edwards, 1995; Loayza et al., 2000a, b). Studies varied with respect to the definition of saving, the use of explanatory variables as well as estimation methods and the country coverage. This annex adds to this literature by testing the role of labour market outcomes and international competitiveness in saving formation - two important factors for Turkey.

Saving determinants are numerous and contested and they vary across institutional sectors. Total saving is often explained by fiscal balances. Most empirical studies find that improved fiscal balances spurs private saving. This is in contrast to the strict version of the Ricardian equivalence theory. The latter predicts that fiscal balances should not have any impact on total domestic saving, as any change in government saving would be offset by an opposite change in private saving. Total saving is also frequently determined by income growth and real interest rates, although the theoretical impact of these two factors is ambiguous (Loayza et al., 2000a; Metin-Ozcan et al., 2003). Regarding household saving, one of the most common determinants is the age structure of the population, relating to the life-cycle hypothesis. According to this hypothesis, people save most in their middle age and dissave when they are young and/or retired.

In the case of Turkey, the profitability of firms related to international competitiveness and the family income distribution reflecting the labour market outcomes seem to affect saving on top of the standard determinants. These two factors are likely to impact on saving in other countries as well. Against this background, this annex attempts to test if the two hypotheses (international competitiveness and labour market) help explain domestic saving on top of standard determinants. To this end, panel estimations of saving equation for a wide range of countries are undertaken.

Data pose significant challenges. Data on saving for a wide range of countries are scarce. Thus, following usual practice, saving is derived from the saving-investment-current account identity (i.e. as a sum of the current account balance and investment). In the estimations, the dependent variable is the ratio of saving to nominal GDP $(S X)$. The labour market effect is approximated with the labour force participation rate $(L F P R)$, i.e. a share of labour force in working age population, since it is more widely available than employment rates. Real effective exchange rate growth is expected to account for international competitiveness (REER), where an increase in REER implies real exchange rate appreciation. The remaining standard determinants of saving include: the age dependency ratio - the share of population below 20 years and above 64 years in population between 20 and 64 years $(A D R)$, GDP growth $(Y)$, fiscal balances as a percentage of nominal GDP $(N G L)$ and real interest rates $(R I R)$. Data are collected mainly from the World Bank World Development Indicator, IMF International Financial Statistics and OECD Economic Outlook Databases. ${ }^{17}$

Given problems with collecting all variables for a wide range of economies for a sufficient long period, three different country groups are selected. The first contains 46 countries for which all variables are available, the second comprises 64 countries, adding countries for which only fiscal data are not available, and the third includes 88 countries, adding countries for which fiscal balances and real effective

17. In a few cases the missing data were directly collected from central banks and national statistical offices. 
exchange rates are not available. ${ }^{18}$ For all three country groups, the series span from 1998 to 2007. To eliminate cyclical movements, estimations are run for 5-year and 10-year averages, resulting in 2-period balanced panel and cross-section estimations (Table A2.1).

Table A2.1. Saving model results

\begin{tabular}{|c|c|c|c|c|c|c|c|c|c|c|c|c|}
\hline \multirow[b]{2}{*}{ Constant } & \multicolumn{2}{|l|}{ [1] } & \multicolumn{2}{|l|}{ [2] } & \multicolumn{2}{|l|}{$[3]$} & \multicolumn{2}{|l|}{ [4] } & \multicolumn{2}{|l|}{ [5] } & \multicolumn{2}{|l|}{ [6] } \\
\hline & $\begin{array}{l}25.19 \\
(1.50)\end{array}$ & $* \star *$ & $\begin{array}{r}26.73 \\
(11.52)\end{array}$ & ** & $\begin{array}{l}13.98 \\
(8.39)\end{array}$ & & $\begin{array}{l}11.37 \\
(1.22)\end{array}$ & $* * *$ & $\begin{array}{l}17.99 \\
(0.62)\end{array}$ & $* * *$ & $\begin{array}{l}17.80 \\
(5.56)\end{array}$ & *** \\
\hline Y & $\begin{array}{l}-1.02 \\
(0.25)\end{array}$ & $* * *$ & $\begin{array}{l}-1.15 \\
(0.42)\end{array}$ & $* * *$ & $\begin{array}{l}-0.06 \\
(0.47)\end{array}$ & & $\begin{array}{l}-0.03 \\
(0.00)\end{array}$ & $* * *$ & $\begin{array}{r}0.15 \\
(0.02)\end{array}$ & 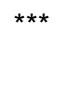 & $\begin{array}{r}0.07 \\
(0.49)\end{array}$ & \\
\hline ADR & $\begin{array}{l}-0.28 \\
(0.03)\end{array}$ & $\star * \star *$ & $\begin{array}{l}-0.34 \\
(0.19)\end{array}$ & * & $\begin{array}{l}-0.36 \\
(0.09)\end{array}$ & $* * *$ & $\begin{array}{l}-0.31 \\
(0.01)\end{array}$ & $* * *$ & $\begin{array}{l}-0.20 \\
(0.01)\end{array}$ & $* * *$ & $\begin{array}{l}-0.20 \\
(0.05)\end{array}$ & *** \\
\hline LFPR & $\begin{array}{r}0.24 \\
(0.03)\end{array}$ & $* * *$ & $\begin{array}{r}0.28 \\
(0.16)\end{array}$ & * & $\begin{array}{r}0.46 \\
(0.15)\end{array}$ & $* \star \star$ & $\begin{array}{r}0.44 \\
(0.01)\end{array}$ & $* \star *$ & $\begin{array}{r}0.22 \\
(0.00)\end{array}$ & 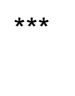 & $\begin{array}{r}0.22 \\
(0.10)\end{array}$ & $* *$ \\
\hline RIR & $\begin{array}{l}-0.27 \\
(0.07)\end{array}$ & $\star \star \star *$ & $\begin{array}{l}-0.37 \\
(0.18)\end{array}$ & ** & $\begin{array}{l}-0.60 \\
(0.21)\end{array}$ & $* \star *$ & $\begin{array}{l}-0.38 \\
(0.11)\end{array}$ & $\star \star \star *$ & $\begin{array}{l}-0.07 \\
(0.05)\end{array}$ & & $\begin{array}{l}-0.10 \\
(0.10)\end{array}$ & \\
\hline REER & $\begin{array}{l}-0.43 \\
(0.01)\end{array}$ & $\star \star \star *$ & $\begin{array}{l}-0.92 \\
(0.62)\end{array}$ & & $\begin{array}{l}-1.37 \\
(0.47)\end{array}$ & $* \star *$ & $\begin{array}{l}-0.49 \\
(0.10)\end{array}$ & $\star \star \star *$ & & & & \\
\hline NLG & $\begin{array}{r}0.92 \\
(0.04) \\
\end{array}$ & $* * *$ & $\begin{array}{r}0.86 \\
(0.28) \\
\end{array}$ & $* \star *$ & & & & & & & & \\
\hline Adj. $R^{2}$ & 0.45 & & 0.47 & & 0.34 & & 0.29 & & 0.16 & & 0.14 & \\
\hline No. of countries & 46 & & 46 & & 64 & & 64 & & 88 & & 88 & \\
\hline No. of periods & 1 & cal & 2 & & 1 & & 2 & & 1 & & 2 & مy \\
\hline
\end{tabular}

Notes: Saving ratio to GDP (SX) is the dependent variable in all specifications. Equations are estimated using the (pooled) least squares estimator over the 1998-2007 period. Standard errors are provided in brackets (based on White robust covariances). ${ }^{\star \star *},{ }^{* *}$, ${ }^{*}$ mark significance at a $1 \%, 5 \%$ and $10 \%$ level.

The results obtained render support for the labour market and international competitiveness mechanisms (Table A2.1). The coefficient of the labour force participation rate is positive and significant across all specifications. Thus, countries with higher shares of people in the labour force are likely to save more. The real effective exchange rate is negative and significant in most specifications, implying that appreciation lowers domestic saving. Regarding the standard determinants of saving, the demographic factor turned significant and in line with expectations. Countries with a higher share of young and old people tend to have lower saving. The fiscal balances also proved significant and positive, implying that an improvement in the budget balance leads to higher overall saving, rebutting Ricardian equivalence. This particular finding should be interpreted with caution as not for all countries the budget balances refer to general government and comply with the same accounting standards. The real interest rate and real growth seems to have a negative impact on saving, though the effect of growth is not robust across different specifications.

18. The first group includes: Australia, Bolivia, Canada, Chile, Costa Rica, Croatia, Georgia, Iceland, Israel, Japan, Korea, Lesotho, Moldova, New Zealand, Nicaragua, Norway, the Russian Federation, Singapore, South Africa, Switzerland, the United States, Uruguay, and EU27 countries excluding Luxembourg, Malta and Portugal; the second group includes in addition to the first group: Belize, Cameroon, China, Côte d'Ivoire, the Dominican Republic, Ghana, Indonesia, Macedonia (FYR), Malaysia, Mexico, Morocco, Paraguay, Philippines, Saudi Arabia, Trinidad and Tobago, Turkey, Ukraine and Venezuela (RB); the third group includes in addition to the second group: Bangladesh, Belarus, Botswana, Brazil, Cambodia, Cape Verde, Hong Kong, Ethiopia, Guatemala, Honduras, Jordan, Mali, Mauritius, Namibia, Panama, Peru, Rwanda, Senegal, Sri Lanka, Swaziland, Thailand and Viet Nam. 
The results obtained are robust to including separately the age dependency ratio for young (ADRY) and old cohorts (ADRO), excluding GDP growth (given possible endogeneity with saving), including gross national income per capita (GNIPC) as a proxy of the income level as well as to including two proxies of institution quality from the World Governance Indicators database - political stability and no violence (WGI2) and rule of law (WGI5) - Tables A2.2-4. 
Table A2.2. Robustness checks of the saving models estimated for the first group of countries

\begin{tabular}{|c|c|c|c|c|c|c|c|c|c|c|c|c|c|c|c|c|c|c|c|c|}
\hline & [1] & & [2] & & [1a] & & [2a] & & [1b] & & [2b] & & {$[1 c]$} & & [2c] & & {$[1 d]$} & & [2d] & \\
\hline \multirow[t]{2}{*}{ C } & 25.19 & $* \star *$ & 26.73 & ** & 23.83 & $\star \star \star *$ & 25.17 & $* *$ & 19.21 & $* * *$ & 21.94 & * & 26.03 & $* * *$ & 28.07 & * & 23.67 & $* * *$ & 24.95 & * \\
\hline & $(1.50)$ & & (11.52) & & $(1.26)$ & & (12.16) & & $(0.44)$ & & (12.77) & & $(0.89)$ & & (14.08) & & $(1.43)$ & & (12.65) & \\
\hline \multirow[t]{2}{*}{ YG } & -1.02 & $* * *$ & -1.15 & $* * *$ & -0.82 & $\star \star \star *$ & -0.90 & * & & & & & -1.04 & $\star * * *$ & -1.19 & $* * *$ & -0.82 & $\star * *$ & -0.88 & * \\
\hline & $(0.25)$ & & $(0.42)$ & & $(0.20)$ & & $(0.46)$ & & & & & & $(0.24)$ & & $(0.38)$ & & $(0.19)$ & & $(0.48)$ & \\
\hline \multirow[t]{2}{*}{ ADR } & -0.28 & $\star * * *$ & -0.34 & * & -0.23 & 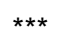 & -0.30 & & -0.27 & $* * *$ & -0.34 & * & & & & & -0.23 & $* * *$ & -0.29 & \\
\hline & $(0.03)$ & & $(0.19)$ & & $(0.03)$ & & $(0.21)$ & & $(0.06)$ & & $(0.20)$ & & & & & & $(0.03)$ & & $(0.21)$ & \\
\hline \multirow[t]{2}{*}{ LFPR } & 0.24 & $* * *$ & 0.28 & * & 0.18 & 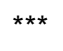 & 0.24 & & 0.26 & $\star * * *$ & 0.29 & & 0.24 & $* * *$ & 0.28 & * & 0.19 & $* * *$ & 0.23 & \\
\hline & $(0.03)$ & & $(0.16)$ & & $(0.03)$ & & $(0.16)$ & & $(0.04)$ & & $(0.18)$ & & (0.03) & & $(0.16)$ & & (0.03) & & $(0.17)$ & \\
\hline \multirow[t]{2}{*}{ RIR3 } & -0.27 & $\star \star \star *$ & -0.37 & $* *$ & -0.29 & $\star \star \star *$ & -0.39 & ** & -0.13 & $\star * \star$ & -0.29 & & -0.27 & $* * *$ & -0.37 & ** & -0.30 & $\star * \star$ & -0.41 & ** \\
\hline & $(0.07)$ & & $(0.18)$ & & $(0.07)$ & & $(0.18)$ & & $(0.01)$ & & $(0.19)$ & & $(0.07)$ & & $(0.18)$ & & $(0.06)$ & & $(0.20)$ & \\
\hline \multirow[t]{2}{*}{ REERG } & -0.43 & $* * *$ & -0.92 & & -0.40 & $* \star *$ & -0.86 & & -0.52 & $\star * *$ & -1.17 & * & -0.43 & $* * *$ & -0.91 & & -0.40 & $* * *$ & -0.92 & \\
\hline & $(0.01)$ & & $(0.62)$ & & $(0.02)$ & & $(0.65)$ & & $(0.00)$ & & $(0.60)$ & & $(0.00)$ & & $(0.60)$ & & $(0.01)$ & & $(0.70)$ & \\
\hline \multirow[t]{2}{*}{ NLGX } & 0.92 & $\star \star \star \star$ & 0.86 & $* * \star$ & 0.85 & $\star \star \star *$ & 0.81 & ** & 0.83 & $* \star \star$ & 0.78 & $\star \star \star *$ & 0.92 & $\star \star \star *$ & 0.85 & $\star \star \star *$ & 0.85 & $* \star \star$ & 0.79 & ** \\
\hline & $(0.04)$ & & $(0.28)$ & & $(0.06)$ & & $(0.33)$ & & $(0.06)$ & & $(0.29)$ & & $(0.04)$ & & $(0.27)$ & & $(0.06)$ & & (0.33) & \\
\hline \multirow[t]{2}{*}{ GNIPC } & & & & & 7E-05 & $* * *$ & $5 \mathrm{E}-05$ & & & & & & & & & & $6 \mathrm{E}-05$ & $* * *$ & 3E-05 & \\
\hline & & & & & $(0.00)$ & & $(0.00)$ & & & & & & & & & & $(0.00)$ & & $(0.00)$ & \\
\hline \multirow[t]{2}{*}{ ADRY } & & & & & & & & & & & & & -0.29 & $* * *$ & -0.35 & * & & & & \\
\hline & & & & & & & & & & & & & (0.03) & & $(0.20)$ & & & & & \\
\hline \multirow[t]{2}{*}{ ADRO } & & & & & & & & & & & & & -0.31 & $* * *$ & -0.38 & & & & & \\
\hline & & & & & & & & & & & & & (0.05) & & $(0.29)$ & & & & & \\
\hline \multirow[t]{2}{*}{ WGI2 } & & & & & & & & & & & & & & & & & -0.27 & $* \star \star$ & 0.61 & \\
\hline & & & & & & & & & & & & & & & & & $(0.05)$ & & (1.91) & \\
\hline \multirow[t]{2}{*}{ WGI5 } & & & & & & & & & & & & & & & & & 0.48 & $* * *$ & 0.05 & \\
\hline & & & & & & & & & & & & & & & & & $(0.14)$ & & $(2.47)$ & \\
\hline Adj. R2 & 0.45 & & 0.47 & & 0.46 & & 0.46 & & 0.38 & & 0.42 & & 0.44 & & 0.46 & & 0.44 & & 0.44 & \\
\hline No. of countries & 46 & & 46 & & 46 & & 46 & & 46 & & 46 & & 46 & & 46 & & 46 & & 46 & \\
\hline No. of periods & 1 & & 2 & & 1 & & 2 & & 1 & & 2 & & 1 & & 2 & & 1 & & 2 & \\
\hline Period unit & 10-year & ave. & 5-year ave & & 10-year & ave. & 5-year ave & & 10-year & ave. & 5-year ave & & 10-year a & ave. & 5-year ave & & 10-year & ive. & 5-year ave & \\
\hline
\end{tabular}

Notes: Saving ratio to GDP (SX) is the dependent variable in all specifications. Equations are estimated using the (pooled) least squares estimator over the $1998-2007$ period. Standard errors are provided in brackets (based on White robust covariances). ${ }^{* \star *},{ }^{* *},{ }^{*}$ mark significance at a $1 \%, 5 \%$ and $10 \%$ level. 
Table A2.3. Robustness checks of the saving models estimated for the second group of countries

ECO/WKP(2010)76

\begin{tabular}{|c|c|c|c|c|c|c|c|c|c|c|c|c|c|c|c|c|c|c|c|c|}
\hline & [4] & & [3] & & [4a] & & [3a] & & [4b] & & [3b] & & {$[4 c]$} & & {$[3 c]$} & & {$[4 d]$} & & [3d] & \\
\hline \multirow[t]{2}{*}{ C } & 11.37 & $* * *$ & 13.98 & & 9.72 & $* * *$ & 11.64 & & 11.26 & $* * *$ & 13.81 & * & 27.45 & $* * *$ & 30.53 & $* *$ & 9.38 & $\star \star \star$ & 10.75 & \\
\hline & (1.22) & & (8.39) & & (1.82) & & (8.52) & & (1.23) & & (8.06) & & $(0.05)$ & & (12.75) & & $(2.14)$ & & (8.80) & \\
\hline \multirow[t]{2}{*}{ YG } & -0.03 & $* * *$ & -0.06 & & 0.14 & & 0.26 & & & & & & -0.30 & $* \star$ & -0.51 & & 0.18 & & 0.34 & \\
\hline & $(0.00)$ & & $(0.47)$ & & $(0.13)$ & & $(0.49)$ & & & & & & $(0.12)$ & & $(0.42)$ & & $(0.13)$ & & $(0.50)$ & \\
\hline \multirow[t]{2}{*}{ ADR } & -0.31 & $* * *$ & -0.36 & $* * *$ & -0.26 & $* * *$ & -0.29 & ** & -0.31 & $* * *$ & -0.35 & $* * *$ & & & & & -0.27 & $* \star *$ & -0.29 & $* *$ \\
\hline & $(0.01)$ & & $(0.09)$ & & $(0.03)$ & & $(0.11)$ & & $(0.01)$ & & $(0.10)$ & & & & & & $(0.03)$ & & $(0.12)$ & \\
\hline \multirow[t]{2}{*}{ LFPR } & 0.44 & $* * *$ & 0.46 & $* * *$ & 0.39 & $* * *$ & 0.40 & ** & 0.44 & $* * *$ & 0.45 & $* * *$ & 0.41 & $* * *$ & 0.43 & $* * *$ & 0.41 & $* * *$ & 0.41 & $* *$ \\
\hline & $(0.01)$ & & $(0.15)$ & & $(0.01)$ & & $(0.16)$ & & $(0.01)$ & & $(0.15)$ & & $(0.01)$ & & $(0.15)$ & & $(0.00)$ & & $(0.16)$ & \\
\hline \multirow[t]{2}{*}{ RIR3 } & -0.38 & *** & -0.60 & $* * *$ & -0.40 & $* * *$ & -0.64 & $* * *$ & -0.38 & $* * *$ & -0.60 & $* * *$ & -0.38 & $* * *$ & -0.57 & $* * *$ & -0.40 & $* * *$ & -0.64 & $* * *$ \\
\hline & $(0.11)$ & & $(0.21)$ & & $(0.12)$ & & $(0.21)$ & & $(0.11)$ & & $(0.21)$ & & $(0.12)$ & & $(0.19)$ & & $(0.13)$ & & $(0.24)$ & \\
\hline \multirow[t]{2}{*}{ REERG } & -0.49 & $* \star *$ & -1.37 & $* * *$ & -0.48 & $* \star *$ & -1.28 & ** & -0.50 & $* * *$ & -1.37 & $* * *$ & -0.47 & $* * *$ & -1.30 & $* * *$ & -0.45 & $* * *$ & -1.22 & $* *$ \\
\hline & $(0.10)$ & & $(0.47)$ & & $(0.09)$ & & $(0.49)$ & & $(0.10)$ & & $(0.45)$ & & $(0.10)$ & & $(0.41)$ & & $(0.09)$ & & $(0.49)$ & \\
\hline \multirow[t]{2}{*}{ GNIPC } & & & & & $8 \mathrm{E}-05$ & $* * *$ & $8 \mathrm{E}-05$ & & & & & & & & & & $8 E-05$ & $\star * *$ & $8 \mathrm{E}-05$ & \\
\hline & & & & & $(0.00)$ & & $(0.00)$ & & & & & & & & & & $(0.00)$ & & $(0.00)$ & \\
\hline \multirow[t]{2}{*}{ ADRY } & & & & & & & & & & & & & -0.45 & $* * *$ & -0.50 & $* * *$ & & & & \\
\hline & & & & & & & & & & & & & $(0.00)$ & & $(0.12)$ & & & & & \\
\hline \multirow[t]{2}{*}{ ADRO } & & & & & & & & & & & & & -0.79 & $\star \star \star *$ & -0.85 & 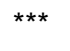 & & & & \\
\hline & & & & & & & & & & & & & $(0.00)$ & & $(0.25)$ & & & & & \\
\hline \multirow[t]{2}{*}{ WGI2 } & & & & & & & & & & & & & & & & & -1.97 & $* *$ & -1.69 & \\
\hline & & & & & & & & & & & & & & & & & $(0.82)$ & & (1.62) & \\
\hline \multirow[t]{2}{*}{ WGI5 } & & & & & & & & & & & & & & & & & 1.19 & & 1.27 & \\
\hline & & & & & & & & & & & & & & & & & $(0.77)$ & & $(2.20)$ & \\
\hline Adj. R2 & 0.29 & & 0.34 & & 0.29 & & 0.34 & & 0.29 & & 0.35 & & 0.34 & & 0.39 & & 0.29 & & 0.32 & \\
\hline No. of countries & 64 & & 64 & & 64 & & 64 & & 64 & & 64 & & 64 & & 64 & & 64 & & 64 & \\
\hline No. of periods & 2 & & 1 & & 2 & & 1 & & 2 & & 1 & & 2 & & 1 & & 2 & & 1 & \\
\hline Period unit & 5-year av & & 10-year a & ive. & 5-year av & & 10-year a & ve. & 5-year ave & & 10-year al & ave. & 5-year av & & 10-year a & ave. & 5-year av & & 10-year a & ave. \\
\hline
\end{tabular}

Notes: Saving ratio to GDP (SX) is the dependent variable in all specifications. Equations are estimated using the (pooled) least squares estimator over the $1998-2007$ period. Standard errors are provided in brackets (based on White robust covariances). ${ }^{* \star *},{ }^{* *},{ }^{*}$ mark significance at a $1 \%, 5 \%$ and $10 \%$ level. 
Table A2.4. Robustness checks of the saving models estimated for the third group of countries

\begin{tabular}{|c|c|c|c|c|c|c|c|c|c|c|c|c|c|c|c|c|c|c|c|c|}
\hline & [5] & & [6] & & [5a] & & [6a] & & [5b] & & {$[6 b]$} & & {$[5 c]$} & & {$[6 c]$} & & {$[5 d]$} & & {$[6 \mathrm{~d}]$} & \\
\hline \multirow[t]{2}{*}{ C } & 17.99 & $\star \star \star *$ & 17.80 & $* * *$ & 15.31 & $* * \star$ & 14.23 & $* *$ & 18.24 & $* \star *$ & 17.88 & $* \star *$ & 31.64 & $* \star *$ & 32.57 & $\star \star \star *$ & 14.61 & $* * *$ & 13.20 & ** \\
\hline & $(0.62)$ & & $(5.56)$ & & $(1.29)$ & & $(6.20)$ & & $(0.46)$ & & $(5.36)$ & & $(0.21)$ & & $(8.25)$ & & (1.09) & & $(6.17)$ & \\
\hline \multirow[t]{2}{*}{$Y G$} & 0.15 & $* * *$ & 0.07 & & 0.32 & $* *$ & 0.44 & & & & & & -0.04 & & -0.31 & & 0.33 & $* *$ & 0.43 & \\
\hline & $(0.02)$ & & $(0.49)$ & & $(0.15)$ & & $(0.53)$ & & & & & & $(0.06)$ & & $(0.47)$ & & $(0.16)$ & & $(0.53)$ & \\
\hline \multirow[t]{2}{*}{ ADR } & -0.20 & $* * *$ & -0.20 & $* * *$ & -0.16 & $* * *$ & -0.15 & $* * *$ & -0.20 & $* \star *$ & -0.20 & $\star * \star *$ & & & & & -0.16 & $* * *$ & -0.14 & ** \\
\hline & $(0.01)$ & & $(0.05)$ & & $(0.02)$ & & $(0.05)$ & & $(0.01)$ & & $(0.05)$ & & & & & & $(0.02)$ & & $(0.06)$ & \\
\hline \multirow[t]{2}{*}{ LFPR } & 0.22 & $* * *$ & 0.22 & $* *$ & 0.20 & $* * *$ & 0.19 & * & 0.23 & 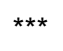 & 0.23 & $\star *$ & 0.19 & $* \star *$ & 0.19 & * & 0.21 & $* \star *$ & 0.20 & ** \\
\hline & $(0.00)$ & & $(0.10)$ & & $(0.02)$ & & $(0.10)$ & & $(0.00)$ & & $(0.11)$ & & $(0.00)$ & & $(0.10)$ & & $(0.02)$ & & $(0.10)$ & \\
\hline \multirow[t]{2}{*}{ RIR3 } & -0.07 & & -0.10 & & -0.08 & & -0.12 & & -0.07 & & -0.11 & & -0.08 & & -0.13 & & -0.09 & * & -0.15 & \\
\hline & $(0.05)$ & & $(0.10)$ & & $(0.05)$ & & $(0.10)$ & & $(0.05)$ & & $(0.09)$ & & $(0.05)$ & & $(0.10)$ & & $(0.05)$ & & $(0.11)$ & \\
\hline \multirow[t]{2}{*}{ GNIPC } & & & & & 0.00 & $* * \star$ & 0.00 & * & & & & & & & & & 0.00 & $\star \star \star *$ & 0.00 & \\
\hline & & & & & $(0.00)$ & & $(0.00)$ & & & & & & & & & & $(0.00)$ & & $(0.00)$ & \\
\hline \multirow[t]{2}{*}{ ADRY } & & & & & & & & & & & & & -0.30 & $* * *$ & -0.30 & $* * *$ & & & & \\
\hline & & & & & & & & & & & & & $(0.01)$ & & $(0.07)$ & & & & & \\
\hline \multirow[t]{2}{*}{ ADRO } & & & & & & & & & & & & & -0.64 & $\star \star \star *$ & -0.66 & $* * *$ & & & & \\
\hline & & & & & & & & & & & & & $(0.02)$ & & $(0.19)$ & & & & & \\
\hline \multirow[t]{2}{*}{ WGI2 } & & & & & & & & & & & & & & & & & -0.51 & $\star * *$ & -0.90 & \\
\hline & & & & & & & & & & & & & & & & & $(0.12)$ & & $(1.24)$ & \\
\hline \multirow[t]{2}{*}{ WGI5 } & & & & & & & & & & & & & & & & & 1.02 & $\star \star \star *$ & 1.68 & \\
\hline & & & & & & & & & & & & & & & & & $(0.07)$ & & (1.69) & \\
\hline Adj. R2 & 0.16 & & 0.14 & & 0.18 & & 0.16 & & 0.16 & & 0.15 & & 0.22 & & 0.20 & & 0.17 & & 0.15 & \\
\hline No. of countries & 88 & & 88 & & 88 & & 88 & & 88 & & 88 & & 88 & & 88 & & 88 & & 88 & \\
\hline No. of periods & 1 & & 2 & & 1 & & 2 & & 1 & & 2 & & 1 & & 2 & & 1 & & 2 & \\
\hline Period unit & 10-year a & ave. & 5-year as & & 10-year & ave. & 5-year av & & 10-year a & ave. & 5-year av & & 10-year a & ave. & 5-year ave & & 10-year a & ave. & 5-year a & ve. \\
\hline
\end{tabular}

Notes: Saving ratio to GDP (SX) is the dependent variable in all specifications. Equations are estimated using the (pooled) least squares estimator over the $1998-2007$ period. Standard errors are provided in brackets (based on White robust covariances). ${ }_{\star \star *},{ }_{\star \star}^{*}$ mark significance at a $1 \%$, $5 \%$ and $10 \%$ level. 


\section{WORKING PAPERS}

The full series of Economics Department Working Papers can be consulted at www.oecd.org/eco/workingpapers/

819. The 2008-09 crisis in Turkey: performance, policy responses and challenges for sustaining the recovery

(December 2010) by Łukasz Rawdanowicz

818. Fiscal-consolidation strategies for Canadian governments

(November 2010) by Yvan Guillemette

817. The land transport sector: policy and performance

(November 2010) by Jan Persson and Daeho Song

816. A simple model of the relationship between productivity, saving and the current account (November 2010) by Jean-Marc Fournier, Isabell Koske

815. The impact of structural policies on saving, investment and current accounts (November 2010) by Clovis Kerdrain, Isabell Koske, Isabelle Wanner

814. Towards a less distortive and more efficient tax system in Portugal (November 2010) by Alvaro Pina

813. Are global imbalances sustainable? Shedding further light on the causes of current account reversals

(November 2010) by Luiz de Mello, Pier Carlo Padoan, Linda Rousová

812. Turkey's improving integration with the global capital market: Impacts on risk premia and capital costs

(November 2010) by Rauf Gönenç, Saygin Şahinöz, Özge Tuncel

811. Trade linkages in the OECD trade system

(October 2010) by Jérôme Brézillon, Stéphanie Guichard and Dave Turner

810. Enhancing the effectiveness of social policies in Indonesia

(October 2010) by Margherita Comola and Luiz de Mello

809. Tackling the infrastructure challenge in Indonesia

(October 2010) by Mauro Pisu

808. Phasing out energy subsidies in Indonesia

(October 2010) by Annabelle Mourougane

807. Implementing cost-effective policies in the United States to mitigate climate change (October 2010) by David Carey

806. Restoring fiscal sustainability in the United States

(October 2010) by Patrick Lenain, Bob Hagemann and David Carey 
805. Norway: Sustainable development: climate change and fisheries policies (September 2010) by Paul O’Brien

804. Netherlands: How the transport system can contribute to better economic and environmental outcomes

(September 2010) by Tomasz Koźluk

803. Public-private partnerships and investment in infrastructure

(September 2010) by Sónia Araújo and Douglas Sutherland

802. Sustaining the momentum of fiscal reform

(September 2010) by Colin Forthun and Robert Hagemann

801. The consequences of banking crises for public debt

(September 2010) by Davide Furceri and Aleksandra Zdzienicka

800. A simulation model of federal, provincial and territorial government accounts for the analysis of fiscal-consolidation strategies in Canada

(September 2010) by Yvan Guillemette

799. Product market regulation: extending the analysis beyond OECD countries

(October 2010) by Anita Wölfl, Isabelle Wanner, Oliver Röhn, Giuseppe Nicoletti

798. Korea's green growth strategy: mitigating climate change and developing new growth engines (July 2010) by Randall S. Jones and Byungseo Yoo

797. Health-care reform in Korea

(July 2010) by Randall S. Jones

796. The Korean financial system: overcoming the global financial crisis and addressing remaining problems

(July 2010) by Masahiko Tsutsumi, Randall S. Jones and Thomas F. Cargill

795. Are global imbalances sustainable? Post-crisis scenarios

(July 2010) by Luiz de Mello and Pier Carlo Padoan

794. Is there a case for carbon-based border tax adjustment? An applied general equilibrium analysis (July 2010) by Jean-Marc Burniaux, Jean Chateau and Romain Duval

793. Promoting potential growth: The role of structural reform (July 2010) by Luiz de Mello and Pier Carlo Padoan

792. Catching-up and inflation in Europe: Balassa-Samuelson, Engel's law and other culprits (July 2010) by Balázs Égert

791. Do product market regulations in upstream sectors curb productivity growth? Panel data evidence for OECD countries

(July 2010) by Renaud Bourlès, Gilbert Cette, Jimmy Lopez, Jacques Mairesse, Giuseppe Nicoletti

790. Preparing for Euro adoption in Poland

(July 2010) by Rafal Kierzenkowski 